Table 1. Parasites collected from ducks on Boundary Bay, B.C., February, 1970.

\begin{tabular}{|c|c|c|c|}
\hline Host & Number & Location & Parasite \\
\hline Goldeneye No. 1 & $\begin{array}{l}100 \text { 's } \\
100 \text { 's }\end{array}$ & $\begin{array}{l}\text { gizzard } \\
\text { intestine } \\
\text { intestine }\end{array}$ & $\begin{array}{l}\text { nematode (F. Trichostrongylidae) } \\
\text { (prob. Trichostrongulus sp) } \\
\text { trematode (F. Echinostomatidae, } \\
\text { (Acanthoparyphium sp) } \\
\text { trematode (F. Strigeidae, } \\
\quad \text { (Apatemen } s p \text { ) }\end{array}$ \\
\hline Goldeneye No. 2 & $\begin{array}{l}20+ \\
1 \\
2 \\
6\end{array}$ & $\begin{array}{l}\text { intestine } \\
\text { gizzard } \\
\text { intestine } \\
\text { intestine }\end{array}$ & $\begin{array}{l}\text { acanthocephalan (Filicollis } s p \text { ) } \\
\text { nematode (O. Oxyruidea) } \\
\text { tapeworm (O. Cyclophyllidea, } \\
\text { prob. Fimbiaria sp) } \\
\text { tapeworm (O. Cyclophyllidea) }\end{array}$ \\
\hline Greater Scaup & $\begin{array}{l}1 \\
1 \\
20+ \\
100 \text { 's } \\
1\end{array}$ & $\begin{array}{l}\text { cloaca } \\
\text { proventriculus } \\
\text { gizzard } \\
\text { intestine } \\
\text { intestine }\end{array}$ & $\begin{array}{l}\text { tapeworm (O. Pseudophyllidea, } \\
\text { Schistocephalus solidus) } \\
\text { nematode, encysted, unident. } \\
\text { nematode (F. Trichostrongylidae) } \\
\text { (prob. Trichostrongulus sp.) } \\
\text { trematode (F. Echinostomatidae) } \\
\text { nematode, unident. }\end{array}$ \\
\hline Oldsquaw No. 1 & $\begin{array}{l}100 ’ s \\
100+\end{array}$ & $\begin{array}{l}\text { intestine } \\
\text { intestine }\end{array}$ & $\begin{array}{l}\text { tapeworm ( } \mathrm{F} \text {. Hymenolepididae) } \\
\text { acanthocephalan (Filicollis } s p \text { ) }\end{array}$ \\
\hline Oldsquaw No. 2 & $\begin{array}{l}100 ’ s \\
50+\end{array}$ & $\begin{array}{l}\text { intestine } \\
\text { intestine }\end{array}$ & $\begin{array}{l}\text { tapeworm (F. Hymenolepididae) } \\
\text { trematode (F. Microphallidae) }\end{array}$ \\
\hline
\end{tabular}

would recover, and at this time it was noticed that they were too weak to be able to dive to any depth for any period of time. The indications therefore are that the direct cause of death was starvation because of an inability to dive for food due to the weakening effects of the parasitic loads.

As a subject of further study this duck-parasite relation seems to have an interesting potential.

\section{NORTHERN SHRIKE CAPTURES SHREW}

by Al Grass, 5666 Rumble St., Burnaby, B.C.

On April 14, 1970 while Glen R. Ryder and myself were studying Short-eared Owls, our attention was drawn to a Northern Shrike in a hawthorn bush about 40 feet from us. The bird had in its possession a small brown animal which we assumed to be a Meadow Vole (Microtus sp.). While the shrike was under observation, it

\section{LITERATURE CITED}

Yamaguti, S., 1958. Systema Helminthum, Vol. 1-5. Interscience Pub. N.Y.

Yorke, W., and P. A. Maplestone. 1962. Hafner Publ. Co. N.Y.

Nematode parasites of vertebrates. Hafner Publ. Co. N.Y.

Skijubin, K. I., N. P. Shiklobalova and R. S. Schultz. 1954. Essentials of nematodology. Acad. of Science of the USSR, Moscow.

Wardle, R. A., and J. A. McLeod. 1952. Zoology of tapeworms. Univ. Minn. Press.

Golvan, A. Y. J. 1964. An illustrated key to the genera of Acanthocephala. Paris Tr. by Ivan Pratt, Dept. of Zool. Oregon State University.

proceeded to impale the animal on a hawthorn spine. We decided to approach more closely and to our surprise the shrike allowed us to come within 10 feet of it and seemed almost defiant. Once the bird flew we examined the small mammal more closely. It proved to be a Cinereus or Masked Shrew (Sorex cinereus). According to the literature, it is apparently uncommon for shrikes to feed on shrews.

The incident took place in the municipality of Delta, some 30 miles from Vancouver, B.C. 